\title{
Pengaruh Pengungkapan CSR Terhadap Kualitas Audit
}

\author{
Ade Elza Surachman* \\ STIE Wibawa Karta Raharja, Purwakarta,Indonesia, adeelza@stiewikara.ac.id
}

ARTICLE INFO

Article history:

Received 5 Agustus 2020

Received in Revised 10 Oktober 2020

Accepted 30 November 2020

Keywords:

internal and external auditors,

good governance

\begin{abstract}
This research aims to test and empirically prove the effect of corporate social responsibility disclosure on the audit quality. Audit quality measurement in this research uses natural logarithm to audit fees while CSR reporting is measured using a content analysis approach. The population of this research is the subsector transportation of companies listed in the Indonesia Stock Exchange in 2010 until 2017. The annual report contains disclosure of corporate social responsibility activities of 4 companies that using a purposive sampling technique. Methods of data analysis using descriptive statistical analysis and simple linear regression. These results indicate that corporate social responsibility disclosures have a significant effect simultaneously and partially on the audit quality.
\end{abstract}

AKUISISI : Jurnal Akuntansi

Website : http://www.fe.ummetro.ac.id/ejournal/index.php/JA

This is an open access article distributed under the terms of the Creative Commons Attribution 4.0 International License, which permits unrestricted use, distribution, and reproduction in any medium, provided the original work is properly cited.

* Corresponding author. Tel.: +0-000-000-0000 ; fax: +0-000-000-0000.

E-mail address:adeelza@stiewikara.ac.id

Peer review under responsibility of Akuisisi : Accounting Journal. 2477-2984.

http://dx.doi.org/10.24217 


\section{INTRODUCTION}

Corporate social responsibility (CSR) akhir-akhir ini menjadi strategi andalan perusahaan untuk meningkatkan pangsa pasarnya. Tanggungjawab sosial yang yang dikemas ke dalam unsur pemasaran yang menggunakan konsep creating shared value (CSV) yang diimplementasikan kepada pelaku bisnis yang merupakan tanggungjawab terhadap masyarakat sekitarnya, hal ini tentunya memberikan respon kepada para stakeholders' untuk berinvestasi dan manfaat produk bagi konsumen dari setiap unit yang dihasilkan (Olavia, 2018). Di samping itu, pentingnya pelaporan CSR dalam pengungkapan laporan non-keuangan dapat meningkatkan kredibilitas atau dengan kata lain memberikan manfaat yang jauh lebih tinggi dibandingkan dengan biaya yang dikeluarkan hingga tahap penerbitan laporan CSR kepada masyarakat (Chen, Srinidhi, Tsang, \& Yu, 2016), hal ini tentunya dimuat ke dalam laporan tahunan yang telah diaudit yang diterbitkan oleh perusahaanperusahaan yang listing di pasar Bursa sebagai pertanggungjawaban sosial kepada masyarakat.

Pelaporan CSR itu sendiri diatur dalam Pasal 1 (ayat 3) Undang-Undang Republik Indonesia Nomor 40 Tahun 2007 tentang Perseroan Terbatas yang menegaskan "Tanggung jawab sosial dan lingkungan adalah komitmen Perseroan untuk berperan serta dalam pembangunan ekonomi berkelanjutan guna meningkatkan kualitas kehidupan dan lingkungan yang bermanfaat, baik bagi Perseroan sendiri, komunitas setempat, maupun masyarakat pada umumnya" (Kayo, 2015). Walaupun telah diatur dalam beberapa ketentuan mengenai CSR perusahaan, CSR itu sendiri juga memiliki masalah dalam penerapannya di Indonesia. Beberapa perusahaan telah melakukan tindakan sukarela dalam konteks implementasi CSR sebagai etika bisnis, hal ini banyak menimbulkan pro dan kontra di kalangan bisnis (Aulia \& Wulandari, 2018), karena investasi pendanaan CSR sangat besar dan hal ini menjadi masalah ketika bisnis mengalami penurunan daya beli sehingga perusahaan tidak melaksanakan aktivitas CSR dan wacana mengenai CSR kurang memiliki apresiasi yang tepat khususnya di perusahaan-perusahaan skala kecil karena: (1) belum adanya batas yang jelas mengenai CSR; (2) banyak perusahaan yang masih cenderung oportunis atau memiliki motif ekonomi; (3) kurangnya respon pemegang kepentingan yang berdampak pada pengendalian sosial; (4) SOP dan undang- undangnya masih lemah serta belum adanya ukuran evaluasi yang jelas (Hadi, 2011, hal. 45).

Kualitas audit itu sendiri dapat dikaji dari beragaman sudut pandang. Salah satu perspektif yang menjadi kian penting adalah outputnya yaitu laporan audit yang menjadi bagian dari kualitas produk sesuai dengan standar yang ditentukan. Produk audit keuangan dipandang di kalangan akademisi dan praktisi dapat berupa opini audit, nana kantor akuntan publik dan juga besaran 
honorarium audit. Penentuan honorarium jasa audit yang terlalu rendah pun menjadi persoalan tersendiri yang menggangu integritas, kualitas dan independesi profesi auditor yang sehat dan kondusif (IAPI, 2016). Produk audit dalam kaitannya dengan pengungkapan CSR dan pemeriksaan terhadap kewajaran pembiayaan CSR perusahaan itu juga menyita waktu auditor untuk melakukan pengujian substansial, hal ini tidak akan menjadi masalah bagi perusahaan-perusahaan dalam kondisi yang ideal atau sehat, tetapi akan menjadi masalah tersendiri dalam perusahaan-perusahaan yang mengalami kesulitan keuangan atau masalah going-concern, penetapan auditor akan cenderung menunjuk pada Kantor Akuntan Publik (KAP) yang mau menerima honorarium atau fee yang rendah sehingga berkemungkinan audit prosedur atas pengungkapan CSR tidak dilaksanakan dengan baik dan akan berdampak pada pertimbangan profesional auditor untuk merilis kategori "unmodified opinion". Sementara perusahaan publik yang berada dalam kondisi kesulitan keuangan akan sebagaimana mungkin untuk mempertahankan opini unmodified opinion jika sebelumnya mendapatkan opini tersebut. Kantor akuntan publik yang berkategori Big-4 hingga saat ini masih dipandang memberikan kualitas audit yang lebih baik dibandingkan dengan selain kategori Big-4 audit (DeFond \& Zhang, 2014). Di samping itu, rencana audit yang memadai dengan mempertimbangkan risiko audit memiliki keterkaitan pengukuran kualitas audit berdasarkan Big $\mathrm{N}$ dan biaya audit yang juga mungkin diduga memiliki pelanggaran independensi yang dilakukan oleh seorang auditor (Rajgopal, Srinivasan, \& Zheng, 2018).

Penelitian mengenai pengungkapan CSR dan audit quality memang telah banyak dilakukan di Indonesia ketika melibatkan faktor-faktor lainnya, seperti yang dilakukan di Amerika Serikat pada laporan CSR yang dirilis perusahaan secara sukarela selama periode 2000-2008 yang menghasilkan temuan penelitian bahwa laporan CSR yang dirilis oleh perusahaan berkomitmen untuk biaya audit yang tinggi dalam mempercepat penggabungan informasi pendapatan masa depan ke dalam harga saham saat ini (Chen, Srinidhi, Tsang, \& Yu, 2016). Kemudian, studi yang dilakukan di perusahaanperusahaan yang terdaftar di selama periode 2003-2012 Chinese A-share menggunakan database CSMAR yang bertujuan meneliti dampak wajib pelaporan CSR atas kualitas laporan keuangan perusahaan dengan implikasi bahwa pengungkapan kewajiban CSR dapat mengurangi asimetri informasi dengan peningkatan kualitas pelaporan keuangan (Wang, Cao, \& Ye, 2016). Studi atas input faktor utama yang menentukan audit quality di Albania yang menggunakan pendekatan interpretif. Instrumen yang digunakan berupa angket yang ditujukan pada legal auditors sebagai sampel penelitian, temuan penelitian ini menghasilkan kualitas audit yang dipersepsikan yang terdiri dari nilai / etika / sikap, aspek yang berkaitan dengan karakteristik pribadi sisi legal seorang auditor (Tanushi, 2019). 
Penelitian di Indonesia yang mengkaitkan antara pengungkapan CSR terhadap audit quality yaitu studi pada perusahaan-perusahaan yang terindeks LQ-45 tahun 2010-2015 yang menggunakan faktor pengungkapan CSR, manajemen laba dan asimetri informasi terhadap cost of equity capital membuktikan bahwa hanya variabel kualitas audit mampu memoderasi hubungan antara pengungkapan CSR dengan cost of equity capital, dimana kualitas audit diukur dengan variabel dummy menggunakan kategori KAP Big-4 dan non Big-4 sementara CSR menggunakan 149 item indikator berdasarkan Global Reporting Initiatives (GRI-4) (Rianingtyas \& Trisnawati, 2017). Studi empiris pada perusahaan yang terdaftar di Bursa Efek Indonesia selama periode 2013 sampai 2016 atas pelaporan CSR dengan komitmen atas audit laporan keuangan dengan proksi biaya audit yang membuktikan hubungan positif pelaporan CSR dengan biaya audit yang pada akhirnya mempengaruhi komitmen terhadap kualitas pelaporan keuangan yang lebih tinggi (Taufik H \& Arifa, 2017). Studi mengenai kesadaran lingkungan dan corporate social responsibility dengan faktor moderasi komite audit untuk mengidentifikasi kualitas laba yang melibatkan sampel 49 industri properti pada perusahaan BUMN dengan temuan yang gagal memprediksi pengaruh CSR terhadap kualitas laba BUMN yang dimoderasi oleh komite audit independen (Witjaksono \& Djaddang,2018).

Hasil penelitian di atas menyimpulkan bahwa pelaporan CSR memiliki dampak pada peningkatan kinerja pelaporan keuangan dan audit quality. Perbedaan penelitian ini yaitu audit quality dengan proksi honorarium audit sementara minimnya penelitian yang menguji langsung kedua faktor ini melatarbelakangi studi ini untuk mengkaji secara spesifik atas pengaruh pengungkapan corporate social responsibility (CSR) terhadap audit quality. Paradigma penelitian ini menggunakan input (data observasi perusahaan yang terdaftar di Bursa Efek Indonesia sub sektor transportasi periode 2010-2017), proses (faktor pengungkapan CSR menggunakan content analysis berdasarkan Global Reporting Initiative Version G4) dan output (audit quality dengan proksi logaritma natural honorarium audit). Pengukuran kualitas audit harus dinilai berdasarkan suatu indeks atau pengukuran / pendekatan tertentu yang dirangkum melalui uji empiris dengan dasar temuan penelitian terdahulu (Husain T. , 2020).

Kehadiran transportasi berbasis aplikasi menjadi persoalan tersendiri yang belum terselesaikan dalam konteks mengikis pendapatan dari para pelaku transportasi konvensional. Menurut Budi Karya (Menteri Perhubungan), CSR dapat menjadi solusi untuk mengatasi kesenjangan kewajiban bagi perusahaan transportasi online dalam memberikan tanggung jawab sosial perusahaan (Purnama, 2017), khususnya bagi perusahaan publik dalam pelaksanaan tanggung jawab sosial atau lingkungan atau dalam tataran global yang disebut sebagai Corporate Social Responsibility ("CSR") yang diatur dalam Pasal 74 Undang-Undang Republik Indonesia Nomor 40 Tahun 2007 tentang Perseroan Terbatas (Kayo, 2015). 
Rancangan kerangka berpikir yang baik tentunya akan menjelaskan secara teoritis hubungan antara variabel yang akan diteliti (Sugiyono, 2016, hal. 91). Kerangka berfikir merupakan model konseptual tentang bagaimana teori berhubungan dengan berbagai faktor yang telah didefinisikan sebagai masalah yang penting. Model itu sendiri merepresentasikan wawasan baru berdasarkan teori empiris dan dapat dikembangkan yang merepresentasikan sistem dan menggantikan system itu sendiri (Holmlund, 2008; Husain T. , 2019), sehingga model penelitian ini dirumuskan sebagai

\section{Gambar. 1 - Model Penelitian}

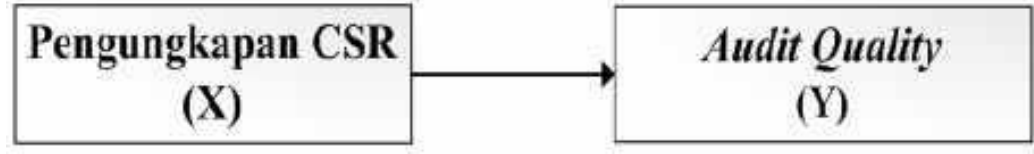

berikut:

Model penelitian di atas dispesifikkan ke dalam rumusan hipotesis alternatif berikut ini:

H0, Pengungkapan Corporate Social Responsibility tidak berpengaruh signifikan terhadap Audit Quality

Ha, Pengungkapan Corporate Social Responsibility berpengaruh signifikan terhadap Audit Quality

\section{METODOLOGI}

\section{JenisPenelitian}

Jenis penelitian ini adalah riset kausalitas yang bertujuan untuk mencari penjelasan dalam bentuk hubungan sebab-akibat (causal effect) antar beberapa variabel. Penelitian ini merupakan applied research untuk mencari faktor penyebab timbulnya masalah sehingga hasilnya dapat digunakan sebagai dasar pemecahan langkah-langkah perbaikan (Supranto \& Limakrisna, 2019, hal. 3). Penelitian ini bertujuan untuk menguji dan membuktikan secara empiris pengaruh pengungkapan laporan corporate social responsibility (CSR) terhadap Audit Quality pada perusahaan-perusahaan yang listing di Bursa Efek Indonesia (BEI).

\section{Populasi dan Sampel}

Populasi penelitian menggunakan 10 (sepuluh) perusahaan Sub Sektor Transporatasi yang terdaftar di Bursa Efek Indonesia (BEI). Sampel penelitian ini ditetapkan berdasarkan teknik purposive sampling dengan kriteria: (1) perusahaan listing di BEI pada Sub Sektor Transportasi selama tahun 2010-2017; 
(2) saham perusahaan tidak di-delisting selama periode pengamatan; (3) dan perusahaan yang menggunakan satuan mata uang selain rupiah (IDR) sebagai mata uang pelaporan akan dikonversikan menggunakan kurs tengah BI. Berdasarkan kriteria di atas, sampel akhir perusahaan ditetapkan sebanyak 4 (empat) perusahaan dengan menggunakan 8 (delapan) tahun periode pengamatan yaitu 2010-2017.

Tabel 1 - Data sampel akhir Perusahaan Sub Sektor Transportiasi yang Terdaftar di BEI tahun 2010-20

Upaya peningkatan dalam proses audit yang memungkinkan individu atau akuntan publik untuk mendeteksi adanya kesalahan atau salah saji dan hasilnya dituangkan dalam output yang berupa laporan auditor independen

\section{Metode Analisis Data}

Metode analisis data menggunakan analisis multivariate. Multivariate berhubungan dengan cara yang dipergunakan dalam pengolahan data dengan menggunakan statistik dalam upaya mencapai tujuan dari suatu penelitian yang menggunakan pendekatan inferensial (Santosa, 2020, hal. 3). Teknik analisis yang digunakan yaitu menggunakan pendekatan dependensi dengan regresi ganda. Model persamaan regresi berganda yaitu:

Tabel 1 - Data sampel akhir Perusahaan Sub Sektor Transportiasi yang Terdaftar di BEI tahun 2010-2017

\begin{tabular}{ccc}
\hline $\begin{array}{c}\text { Kode } \\
\text { Saham }\end{array}$ & \multicolumn{1}{c}{ Nama Emiten } & \\
& & Tanggal IPO \\
\hline APOL & PT Arpeni Pratama Ocean Line Tbk. & 22 Juni 2005 \\
HITS & & \\
WEHA & PT Humpuss Intermoda Transportasi Tbk. & 15 Desember 1997 \\
ZEBRA & PT Weha Transportasi Indonesia Tbk. & 3 Mei 2007 \\
& PT Zebra Nusantara Tbk. & 1 Agustus 1991 \\
& & 4 Perusahan \\
\hline
\end{tabular}

Sumber: (Saham OK, 2020)

$$
Y=\alpha+\beta X+e
$$


Keterangan:

Y : Variabel audit quality

$\alpha \quad$ : Konstanta

$\beta \quad$ : Koefisien regresi

variable independen $\mathrm{X}$ :

Pengungkapan CSR

e : error, yaitu tingkat kesalahan

Uji hipotesis dilakukan dengan tahapan yaitu: (1) uji koefisien determinasi (R-Square), uji hipotesis secara simultan (ANOVA) dan uji hipotesis secara parsial (Uji-t). Penelitian ini menggunakan program SPSS for Windows Version 24.00 dalam pengolahan data.

\section{HASIL DAN PEMBAHASAN}

\section{HasilPenelitian}

Tabel 3 - Hasil Statistik Deskriptif

Descriptive Statistics

\begin{tabular}{lrrrrr}
\hline & N & \multicolumn{1}{c}{ Minimum } & \multicolumn{1}{c}{ Maximum } & \multicolumn{1}{c}{ Mean } & \multicolumn{1}{c}{ Std. Deviation } \\
\hline Pengungkapan CSR & 32 & 0,1099 & 0,4615 & 0,287438 & 0,0989090 \\
Audit Quality & 32 & 250250000 & 3607500000 & 1433507954 & 1158455963 \\
Valid N (listwise) & 32 & & & & \\
\hline
\end{tabular}

Sumber: Output SPSS Ver24 (2020)

Hasil analisis statistik deskriptif atas variabel Pengungkapan CSR (X) mempunyai skor ratarata sebesar 0,2874 dengan skor minimum dan maksimum yang berkisar antara 10,99 persen hingga 46,15 persen, artinya pengungkapan corporate social responsibility pada perusahaan sub sektor Transportasi yang terdaftar di Bursa Efek Indonesia periode 2010-2017 masih tergolong rendah dengan rata-rata 28,74 persen. Variabel Audit Quality yang dihitung dengan pengukuran honorarium audit mempunyai besaran senilai $\mathrm{Rp}$ 1.433.507.984,- dengan besaran minimum dan maksimum yang berkisar antara Rp250.250.000,- hingga Rp3.607.500.000,-, artinya audit quality pada perusahaan sub sektor Transportasi yang terdaftar di Bursa Efek Indonesia periode 20102017 tergolong cukup tinggi dengan rata-rata besaran honorarium senilai Rp 1.433.507.954,-. 
Uji asumsi klasik pada penelitian ini diawali dengan uji normalitas data menggunakan teknik melihat grafik histogram.

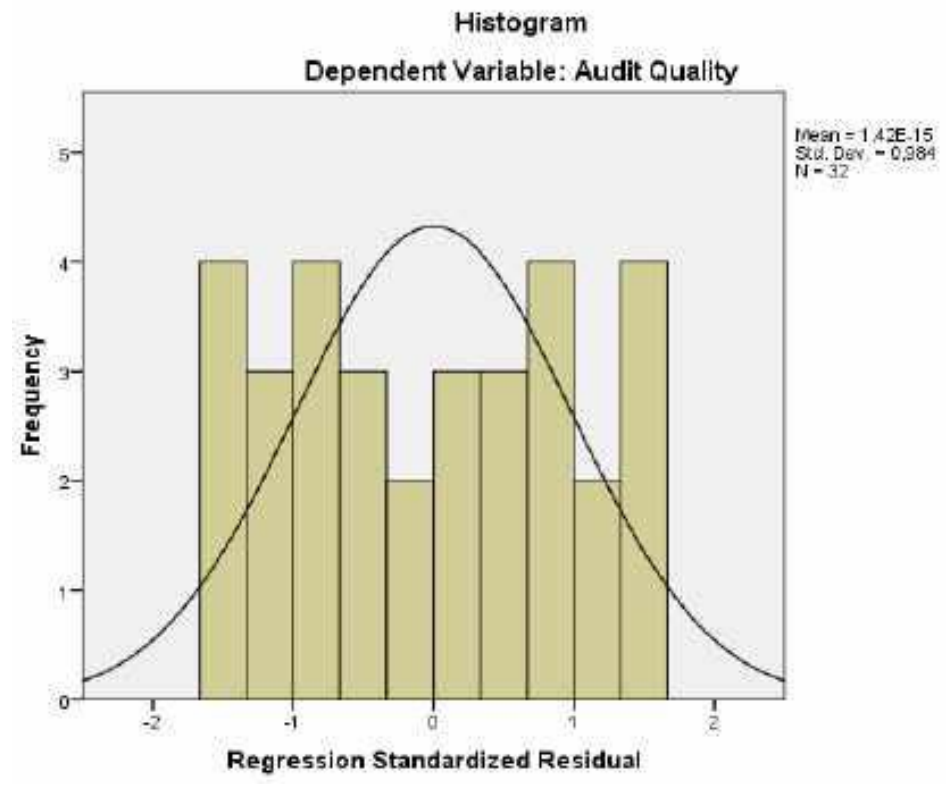

Sumber: Output SPSS Ver24 (2020)

\section{Gambar. 2 - Histogram Uji Normalitas}

Grafik histogram yang ditampilkan atas variabel Audit Quality, dimana nilai residual data telah menunjukkan kurva normal yang membentuk lonceng sempurna. Selanjutnya, dilakukan uji heteroskedastisitas dengan melihat scatter diagram.

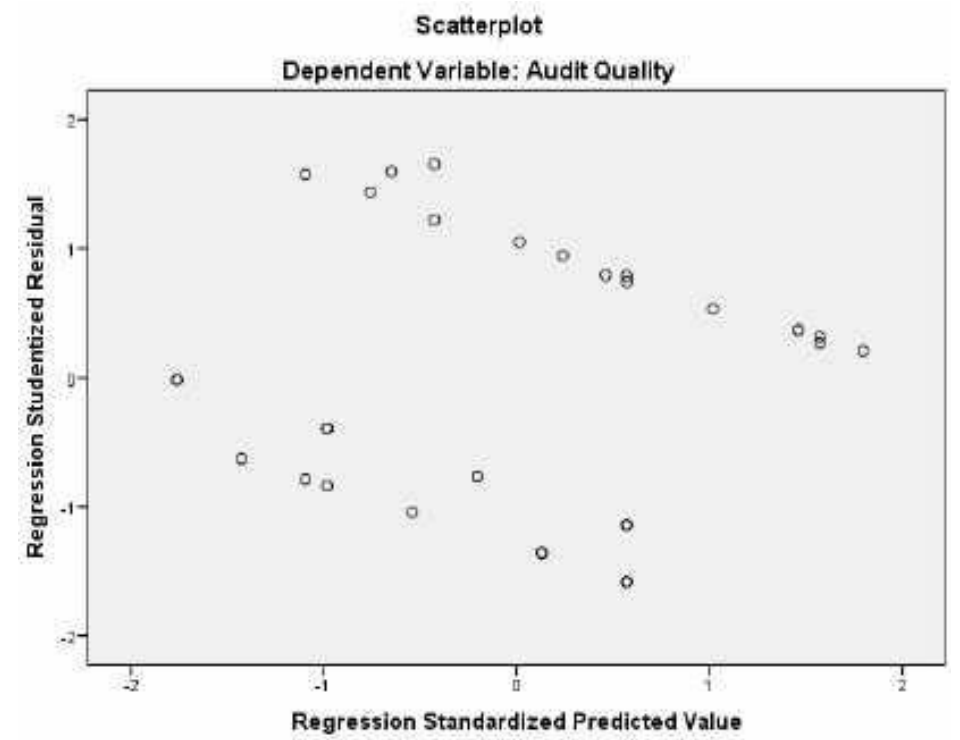

Gambar. 3 - Scatter Diagram Uji Heteroskedastisitas 
Scatterplot yang ditampilkan atas variabel Audit Quality, dimana menunjukkan titik-titik yang menyebar di atas dan di bawah angka 0 dan sumbu Y, yang berarti bahwa model penelitian ini telah terbebas dari heteroskedastisitas antar variabel penelitian. Selanjutnya, dilakukan uji multikolinearitas dengan melihat besaran nilai tolerance dan VIF (variance inflation factor).

Tabel 4 - Hasil Uji Multikolinearitas

\section{Coefficients $^{a}$}

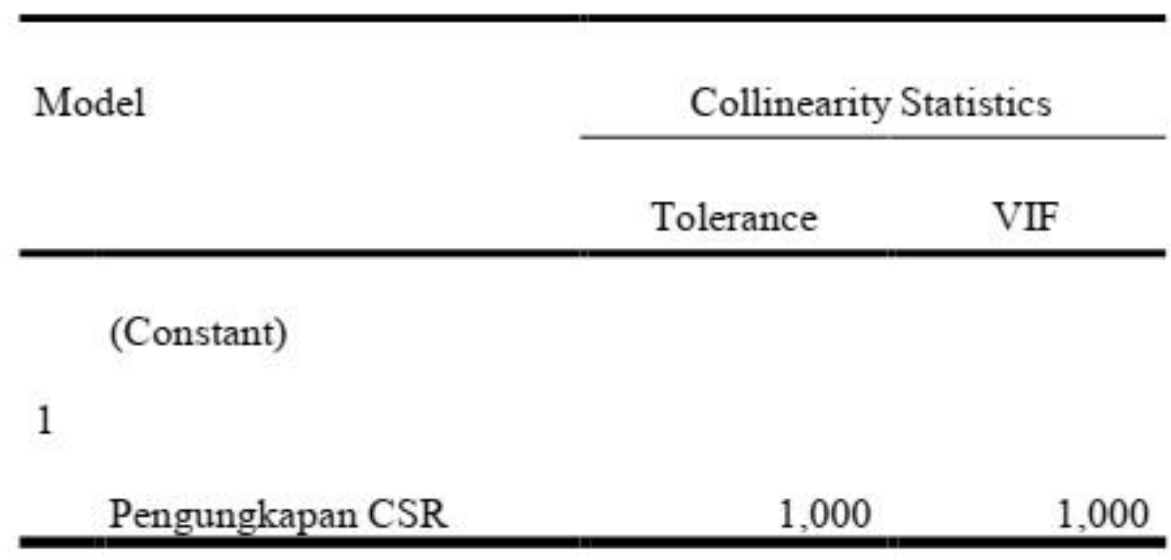

Sumber: Output SPSS Ver24 (2020)

Scatterplot yang ditampilkan atas variabel Audit Quality, dimana menunjukkan titik-titik yang menyebar di atas dan di bawah angka 0 dan sumbu $\mathrm{Y}$, yang berarti bahwa model penelitian ini telah terbebas dari heteroskedastisitas antar variabel penelitian. Selanjutnya, dilakukan uji multikolinearitas dengan melihat besaran nilai tolerance dan VIF (variance inflation factor).

Hasil uji multikolinearitas menghasilkan nilai tolerance pada masing-masing variabel independen lebih besar $(>)$ daripada 0,1 dan nilai VIF kurang dari $(<)$ daripada 10. Dengan demikian, dapat disimpulkan bahwa model regresi terbebas dari multikolineartias antar variabel independen. Selanjutnya, dilakukan uji autokorelasi dengan melihat besarnya nilai Durbin Watson $(\mathrm{dW})$. 
Tabel 5 - Hasil Uji Autokorelasi

Model Summary ${ }^{\mathrm{b}}$

\begin{tabular}{llll}
\hline Model & R Square Adjusted R Square Std. Error of the
\end{tabular}

Durbin-Watson

Estimate

\begin{tabular}{llllrl}
\hline \multicolumn{4}{c}{ Estimate } & \multicolumn{3}{c}{. } \\
\hline 1 &, 098 &, 010 & $-0,023$ & 0,48618 & 1,775 \\
\hline
\end{tabular}

a. Predictors: (Constant), Pengungkapan CSR

b. Dependent Variable: ABS

Sumber: Output SPSS Ver24 (2020)

Hasil uji autokorelasi menghasilkan skor Durbin Watson (dW) sebesar 1,775. Nilai dU dan dL diperoleh masing-masing sebesar 1,282 dan 1,160. Ketentuan uji autokorelasi mensyaratkan bahwa model regresi berada di antara nilai $\mathrm{dU} \leq \mathrm{dW} \leq(4-\mathrm{dU})$. Nilai $\mathrm{dW}$ tersebut berada pada interval yang dipersyaratkan sehingga model regresi tidak menunjukkan adanya autokorelasi positif atau negatif. Setelah dilakukan uji asumsi klasik, langkah selanjutnya yaitu dilakukan uji hipotesis penelitian.

Tabel 6 - Hasil Uji Koefisien Determinasi $\mathrm{R}^{2}$

Model Summary ${ }^{\mathrm{b}}$

Model R R Square Adjusted R Square Std. Error of the

Durbin-Watson

\begin{tabular}{llllrr}
\multicolumn{5}{c}{ Estimate } \\
\hline 1 & $434^{\mathrm{a}}$ & 0,188 & 0,161 & 0,9909944 & 0,504 \\
\hline
\end{tabular}

\footnotetext{
a. Predictors: (Constant), Pengungkapan CSR

b. Dependent Variable: Audit Quality

Sumber: Output SPSS Ver24 (2020)
}

Hasil uji koefisien determinasi menghasilkan skor 0,188 , artinya hanya 18,8 persen perubahan pada variabel audit qulity dapat dijelaskan oleh variabel pengungkapan CSR sebesar 81,2 persen diterangkan oleh variabel lain yang tidak diteliti. Selanjutnya dilakukan uji-F untuk melihat pengaruh secara simultan 
ANOVA $^{\mathrm{a}}$

\begin{tabular}{|rl|r|r|r|r|r|}
\hline Model & Sum of Squares & df & Mean Square & \multicolumn{1}{c|}{ F } & Sig. \\
\hline \multirow{3}{*}{1} & Regression & 6,837 & 1 & 6,837 & 6,962 &, $013^{\circ}$ \\
& Residual & 29,462 & 30 &, 982 & & \\
& Total & 36,299 & 31 & & & \\
\hline
\end{tabular}

a. Dependent Variable: Audit Quality

b. Predictors: (Constant), Pengungkapan CSR

Sumber: Output SPSS Ver24 (2020)

Hasil uji-F menghasilkan probabilitas signifikansi sebesar 0,013, artinya nilai signifikansi kurang dari $(<)$ dari $\quad=5 \%$ sehingga variabel independen pada penelitian ini yaitu Pengungkapan CSR secara simultan berpengaruh signifikan terhadap Audit Quality. Uji hipotesis menggunakan model analisis regresi sederhana melalui uji signifikansi parameter individual (Uj-t).

Tabel 8 - Hasil Uji-t

1.1.1.1 Coefficients ${ }^{a}$

\begin{tabular}{|c|r|r|c|c|r|}
\hline Model & \multicolumn{2}{|c|}{ Unstandar } & Standard & \multirow{2}{*}{$\mathrm{t}$} & Sig. \\
\cline { 2 - 4 } & $\mathrm{B}$ & \multicolumn{1}{|c|}{ Std. } & $\mathrm{Be}$ & & \\
\hline (Constant) & 21,9 &, 54 & & 40,2 &, 00 \\
\hline
\end{tabular}

a. Dependent Variable: AuditQuality

Sumber: Output SPSS Ver24 (2020)

Hasil uji-t menghasilkan nilai t-statistik sebesar -2,638 dengan probabilitas signifikansi sebesar 0,013 , artinya nilai probabilitas signifikansi kurang dari $(<)$ dari $=5 \%$ sehingga variabel independen pada penelitian ini yaitu Pengungkapan CSR secara parsial berpengaruh signifikan terhadap Audit Quality. Hasil persamaan regresi linier sederhana yang dihasilkan oleh Output SPSS Versi 24.00 yaitu:

$$
\mathrm{Y}=21,966-4,748 \mathrm{X}+\mathrm{e}
$$

Constant : 21,966, artinya jika Pengungkapan CSR (X) dianggap konstan, maka besarnya Audit Quality adalah21,966satuan. PengungkapanCSR(X) : Koefisien regresi untuk 
variabel independen Pengungkapan CSR (X) sebesar minus 4,747 dapat diartikanbahwa setiap penambahan satu satuan Pengungkapan CSR, maka berdampak secara signifikan pada penurunan Audit Quality sebesar 4,747 satuan.

\section{Pembahasan}

Hipotesis alternatif (Ha) menyatakan bahwa Pengungkapan CSR berpengaruh signifikan terhadap Audit Quality. Berdasarkan perhitungan analisis regresi linear berganda, diperoleh nilai koefisien regresi sebesar $-4,748$ dengan probabilitas sebesar 0,013. Temuan ini menunjukkan bahwa Pengungkapan CSR terbukti berpengaruh signifikan terhadap Audit Quality. Hasil penelitian ini mendukung temuan terdahulu yang membuktikan bahwa biaya audit yang tinggi berkorelasi dengan komitmen pelaporan CSR perusahaan yang bertujuan untuk penggabungan informasi atas harga saham masa depan (Chen, Srinidhi, Tsang, \& Yu, 2016) dan juga dampak peningkatan kualitas laporan keuangan perusahaan dengan adanya kewajiban CSR yang bertujuan awalnya untuk mengurangi adanya asimetri informasi (Wang, Cao, \& Ye, 2016). Temuan penelitian ini juga sejalan dengan pengaruh signifikan faktor pengungkapan CSR sebagai fungsi moderasi dalam mengukur Cost of Equity Capital, dimana pengungkapan CSR yang lebih dapat menurunkan audit quality, hal ini dikarenakan akan menyita waktu dalam pengujian pengendalian internal dan substansial, khususnya bagi KAP selain Big-4 yang menerima honorarium audit yang jauh lebih rendah daripada KAP Big-4 sehingga prosedur audit atas pengungkapan CSR tidak dilaksanakan dengan sebagaimana mestinya.

\section{KESIMPULAN}

Berdasarkan hasil penelitian dan pembahasan, maka kesimpulan hasil penelitian yaitu:

1. Hasil statistik deskriptif menghasilkan rata-rata honorarium audit senilai yaitu Rp1.433.507.954,-, artinya audit quality pada perusahaan sub sektor Transportasi yang terdaftar di Bursa Efek Indonesia periode 2010-2017 tergolong cukup tinggi.

2. UjihipotesismenghasilkanpengaruhPengungkapanCSRsecarasignifikanterhadapAuditQualityyan gmenghasilkanprobabilitassignifikansisebesar 0,013.

Berdasarkan hasil penelitian dan pembahasan, maka rekomendasi atau saran penelitian ini yaitu:

1. Proksiauditqualitydiharapkandapatdievaluasitidakhanyaberdasarkanpengukuranhonorariumaudi tmelainkanmenggunakanproksi-proksilainnya sepertiukuranKantorAkuntanPublik(KAP)kategoriBig-4dannonBig4 ,tenuraudit,pergantianauditor,danproksilainnya. 
2. Perluasan objek penelitian dapat dikembangkan pada penelitian mendatang tidak hanya terbatas pada perusahaan Sub Sektor Transportasi saja melainkan Sub Sektor lainnya yang terdaftar di Bursa Efek Indonesia (BEI) misalnya sector Aneka Industri, dan sector lainnya.

3. Penambahan faktor-faktor lainnya untuk memprediksi audit quality seperti rasio keuangan, good corporate governance, variabel ekonomi serta pengukuranlainnya.

\section{Acknowledgements}

Saya memanjatkan puji syukur kehadirat Allah SWT atas rahmat dan karunia-Nya sehingga artikel ini dapat diselesaikan untuk dipublikasikan. Ucapan terima kasih ini ditujukan kepada STIE Wibawa Karta Raharja dan Universitas Muhammadiyah Metro yang memberi kesempatan untuk mempublikasikan hasil penelitian ini serta masukan-masukan dari editor dan reviewer dan sangat berharga dalam penyempurnaan isi artikel mengenai Auditing.

\section{REFERENCES}

Aulia, R., \& Wulandari, T. (2018, Juni 28). Problematika Corporate Social Responsibility (CSR) Dalam Penerapannya di Indonesia. Debat Soal Minta CSR BUMN, Disebut Bukan Kegiatan yang Harus Diawasi DPR. Kompasiana.

Chen, L., Srinidhi, B., Tsang, A., \& Yu, W. (2016). Audited Financial Reporting and Voluntary Disclosure of Corporate Social Responsibility (CSR) Reports. Journal of Management Accounting Research, 28 (2 (Summer)), 1-42.

DeFond, \& Zhang, J. (2014). A review of archival auditing research. Journal of Accounting and Economics, 58(2-3), 275-326.

Hadi, N. (2011). Corporate Sosial Responsibility. Yogyakarta: Graha Ilmu.

Haniffa, R. M., \& Cooke, T. (2005). The impact of culture and governance on corporate social reporting. Journal of Accounting and Public Policy, 24(5), 391-430. Holmlund, M. (2008). A Definition, Model, and Empirical Analysis of Business-To-Business. International Journal of Service Industry and Management, 19(1), 32- 62.

Husain, T. (2019). An Analysis of Modeling Audit Quality Measurement Based on Decision Support Systems (DSS). European Journal of Scientific Exploration, 2(6), 1-9.

Husain, T. (2020). Mapping Evolution of Audit Quality Measurement. European Journal of Business and Management Research, 5(3), 1-7.

IAPI. (2016). Peraturan Pengurus Nomor 2 Tahun 2016 tentang Penentuan Imbalan Jasa Audit Laporan Keuangan. Jakarta: Institut Akuntan Publik Indonesia

Kayo, E. S. (2015). CSR - Corporate Social Responsibility. Retrieved Mei 9, 2020, from Saham OK: https://www.sahamok.com/csr/ 
Olavia, L. (2018). Unsur Pemasaran dalam Program CSR Dinilai Sah. Retrieved Mei 8, 2020, from Suara Pembaruan: https://www.beritasatu.com/ekonomi/507695-unsur-pemasarandalam-program-csr-dinilai-sah

Purnama, R. (2017). Pemerintah Bebankan CSR bagi Perusahaan Transportasi Online. Retrieved Mei 7, 2020, from https://www.cnnindonesia.com/teknologi/20170405130543-384-205100/pemerintahbebankan-csr-bagi-perusahaan-transportasi-online

Rajgopal, S., Srinivasan, S., \& Zheng, X. (2018). Measuring Audit Quality. Hawaii International Conference on System Sciences 2018 (pp. 1-64). Honolulu: University of Hawai'i at Manoa.

Rianingtyas, R. A., \& Trisnawati, R. (2017). Pengaruh Pengungkapan CSR, Manajemen Laba dan Asimetri Informasi terhadap Cost of Equity Capital dengan Kualitas Audit sebagai Variabel Moderating pada Perusahaan yang Terdaftar di Indeks LQ-45 Tahun 2010-2015. Seminar Nasional dan The 4th Call for Syariah Paper (pp. 157-171). Surakarta: FEB Universitas Muhammadiyah Surakarta.

Saham OK. (2020). Sub sektor transportasi BEI (74) - Industri Jasa. Retrieved May 22, 2020, from https://www.sahamok.com/emiten/sektor- infrastruktur-utilitas-transportasi/sub-sektortransportasi/

Santosa, A. D. (2020). Analisis Multivariat (Cetakan Keempat) (3 ed.). Yogyakarta: Penerbit Kepel Press. Sugiyono. (2016). Metode Penelitian Kombinasi (Mixed Methods). (M. Sutopo, Ed.) Bandung: CV. Alfabeta.

Supranto, J., \& Limakrisna, N. (2019). Petunjuk Praktis Penelitian Ilmiah untuk Menyusun Skripsi, Tesis dan Disertasi (5 ed.). Bogor: Penerbit Mitra Wahana Media.

Tanushi, E. (2019). Input Factors Determining Audit Quality in Albania. Mediterranean Journal of Social Sciences, 10(5), 99-114.

Taufik H, M., \& Arifa, C. (2017). Pengaruh Pelaporan Corporate Social Responsibility terhadap Komitmen Audit Laporan Keuangan (Studi Empiris pada Perusahaan yang Terdaftar di Bursa Efek Indonesia Tahun 2013-2016). Yogyakarta: Skripsi Universitas Gajah Mada.

Wang, X., Cao, F., \& Ye, K. (2016). Mandatory Corporate Social Responsibility (CSR) Reporting and Financial Reporting Quality: Evidence from a Quasi-Natural Experiment. J Bus Ethics, $152,253-274$.

Witjaksono, R. B., \& Djaddang, S. (2018). Valuasi kesadaran lingkungan, corporate social responsibility terhadap kualitas laba dengan moderasi komite audit. Jurnal Ekonomi dan Bisnis, 21(1), 97-114. 